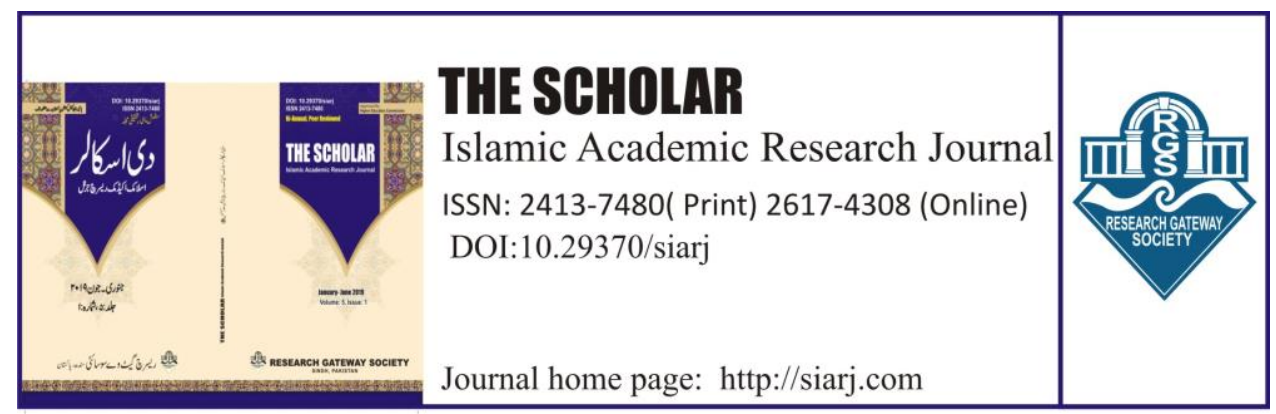

\title{
APPRAISAL OF ISLAMIC DEMOCRATIZATION IN ZIA UL-HAQ REGIME
}

\section{Muhammad Ibrahim}

PhD. Scholar \& Associate professor Political Science Government Post graduate Bahawalnagar, Pakistan

Email: prof.ibrahim69@yahoo.com

ORCID ID

https://orcid.org/0000-0002-9621-6476

\section{Razia Musarrat}

Dean Faculty of Islamic Learning and Chairperson of Political Science Department, The Islamia University of Bahawalpur, Pakistan Email: drrazia_mussarat@yahoo.com ORCID ID:

https://orcid.org/0000-0001-5658-7400

To cite this article:

Ibrahim, Muhammad, and Razia Musarrat. "ENGLISH-APPRAISAL OF ISLAMIC DEMOCRATIZATION IN ZIA UL-HAQ REGIME.” The Scholar-Islamic Academic Research Journal 5, no. 1 (February 11, 2019): 32-48.

To link to this article:

https://doi.org/10.29370/siarj/issue8ar10

\begin{tabular}{ll} 
Journal & The Scholar Islamic Academic Research Journal \\
& Vol. 5, No. 1 || January -June 2019 || P. 32-48 \\
Publisher & Research Gateway Society \\
DOI: & 10.29370/siarj/issue8ar10 \\
\hline URL: & https://doi.org/10.29370/siarj/issue8ar10 \\
\hline License: & Copyright c 2017 NC-SA 4.0 \\
Journal homepage & www.siarj.com \\
Published online: & 2019-02-11
\end{tabular}

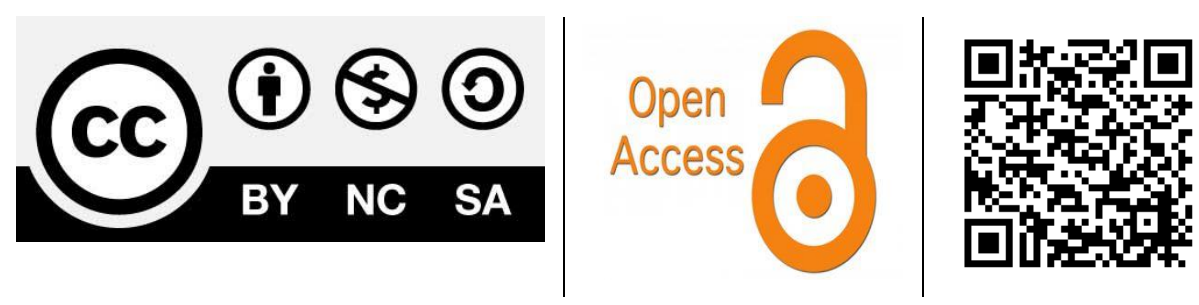


THE SCHOLAR (January - June 2019)

\title{
APPRAISAL OF ISLAMIC DEMOCRATIZATION IN ZIA UL-HAQ REGIME
}

\author{
Muhammad Ibrahim, Razia Musarrat
}

\begin{abstract}
:
Pakistan established on ideological basis. The core objective is to run the state on the principle of Islam. Islam as religion stresses on the consultancy to govern Muslim state. From the beginning of Islam, all the caliphs adopted the process of advisory council which led to democratization in those periods. There is hot debate on the democratic system in Pakistan. The majority of people wished the Islamic governing system. There is serious and hot discussion with different references in the history of Pakistan. There are different views on the Islamization policy of General Zia-ul-Haq. Political decisions were made to democratize the society on Islamic principles. There were different merits and demerits of the regime in Pakistan. The prime objective of study is to focus the Islamic democratization in Zia-ul-Haq regime. The descriptive and analytical method is adopted for the study.
\end{abstract}

KEYWORDS: Zia-ul-Haq, Islamic Governing System in Pakistan, Islamic Democracy, 1slamization of Law, History of Islamic Democratization

\section{INTRODUCTION}

Muslim leadership of subcontinent was focusing to establish a Muslim state in which Muslims could be live life with accordance of Islam. Pakistan was established as a separate state on the map of world for the Muslim of South Asia on August 14, 1947. Although, there was clear majority of Muslim in Pakistan but has unique social structure due to homogeneous society. It was observed as, "Pakistan is anything but a homogenous society being the home of numerous ethnic groups, each with their own sets of social more today's Pakistani social, political and 
economic structure is the result of the colonial policies which were carried out by Great Britain",

Muslims of Pakistan wished Islamic governing system in Pakistan which could be done through constitutionalizing. It was focused during the constitutional developments. The Objective Resolution was land mark achievement in constitutional development in regard of Islamization. Objective Resolution made part of Constitution of 1973. The constitutional developments have core focus for this purpose.

There were civil as well as military governments in Pakistan. The military establishment was considered the custodian of state ideology. Therefore, it took over the governing system more than 30 years in Pakistan. There were different opinions from the perspective of military involvement in political activities in the governing system of Pakistan. political situation was obvious and it was observed by Muhammad Waseem, "The tussle over control of ideological power bases has been endemic to the politics of Pakistan." Further he explained as,

"The ruling elite opted for Islam as an instrument of policy. It conceived religion as a counterweight to demands of leftist groups and ethnic parties to open up the state system to a wider section of the society. Under bureaucracy, and later the army, a democratic framework based on a mass mandate was considered dysfunctional. Therefore, the state elite used Islamic ideology and shaped its idiom. It sought to control ever more

\footnotetext{
${ }^{1}$ Mohammad Waseem, "Functioning of Democracy in Pakistan," in Democracy in Muslim Societies: The Asian Experience, ed. Zoya Khan (New Delhi: SAGE Publications, 2007), 180.
} 
aspects of Islamic theory and practice, by passing legislation in the name of Shariat, assuming control over madrasahs and shrines and influencing the growth patterns of Islamic groups and networks".2

The movement of implementation of Nizam-e-Mustafa gave opportunity to military establishment to get the control of government of Pakistan. There was opinion that General Zia-ul-Haq raised the slogan of Islamic governing system for the legitimacy from public of Pakistan.

\section{HISTORICAL BACK GROUND OF ISLAMIC DEMOCRATIZATION}

Islamic civilization had great contribution on the different fronts in the history of the world. The predominant preview of the West for democracy was antithetical in the Islam. It was legacy of ignoring Islam and Middle East from the past democratic work. There were many scholars who contribute in the shape of their work. The democratization was spread throughout the globe. Therefore, it had to be studied in the whole world in different regions as democracies of Latin America, Asia and Africa. Harold Rogers included some contribution of Muslim countries for the reference of roots for the Islamic democracy ${ }^{3}$ John Keane had a lot of work on the legacy of Islam for democratization. He paid great tribute for the vital contribution of Islam for geographically expansion, enlivening and the basic principles for public gathering of assemblies and equal in governing system. ${ }^{4}$

\footnotetext{
${ }^{2}$ Mohammad Waseem, The 2002 Elections in Pakistan (Islamabad: Quaid-i-Azam University, International Relations, 2003), 55.

${ }^{3}$ Harold Rogers, The History of Democracy: From the Middle East to Western Civilisation (Bloomington: AuthorHouse, 2007).

${ }^{4}$ J. Keane, The Life and Death of Democracy (New York: Simon and Schuster, 2009), 128.
} 
The doctrine of Islam had consisted of all the basic principles, where the Holy Quran recognized the principle of equality. The teachings of the Holy Quran condemned all the discriminations and prejudices that were based on tribalism. The religion was not in favor of racism. ${ }^{5}$ It stated as, "There is no compulsion in religion and that all children of Adam are honorable, regardless of faith, colour, gender or race"6

The democratic process stressed on human rights, equality and social justice. Islam was also focusing on the basic rights of human being. It has great impact for principle of collective humanity. The democratic principles were consisted of tolerance, freedom of expression, equality and political participation. The values were seen from the advent of Islam. The companions of Muhammad (peace be upon him) were fully consulted on the issues of society, governance and religion. There was tolerance for other communities. It was clearly seen in the treaty that was decided between Hadrat 'Umar bin Al Khattāa and Christian Patriarch of Jerusalem. It was stated:

"Their churches are not to taken, nor are they to be destroyed, nor are they to be regarded or belittled, neither are their crosses or their money and they are not to be forced

\footnotetext{
${ }^{5}$ Al-Quran, 49:13.

${ }^{6}$ Al-Quran, 2:265; 17:70.
} 
to change their religion, nor is any one of them to be harmed."7

There was freedom of expression in the Islam that was quoted from the Islamic sources by the Hasim Kamali as, "The ability of the individual to say or do what he or she wishes, or to avoid doing so, without violating the rights of others, or the limits that are set by the law". 8

\section{HISTORICAL BACKGROUND OF DEMOCRATIZATION IN PAKISTAN}

After the death of Quid-i-Azam Mohammad Ali Jinnah his loyal fellow Liaquat Ali Khan piloted nation. After some period, he was assassinated on October 16, 1951. Then there was no choice for the people to hope for the vision of democratic Pakistan. The most significant and enlightening credentials was the approval of the Objective Resolution in the constitutional development history of Pakistan. When the Constituent Assembly approved the Objective Resolution Prime Minister of Pakistan Liaqat Ali Khan expressed his views about this resolution as, "the most important occasion in the life of this country, next in importance only to the achievement of independence." 9

In this Constituent Assembly Muslim League has clear majority. Muslim league could not perform properly in the provinces as well as national level due to lack of proficient and farsighted political leadership.

\footnotetext{
${ }^{7}$ T. W. Arnold, Preaching of Islam: A History of the Propagation of the Muslim Faith (India: Adam Publisher \& Distributor, 2001), 55.

${ }^{8}$ M. H. Kamali, Freedom, Equality and Justice in Islam (Kuala Lumpr: Ilmaih, 2002), 7.

${ }^{9}$ M. Rafique Afzal, Political Parties In Pakistan 1947-1958, vol. 1 (Islam Abad: National Institue of Historical and Cultural Research., 1998), 218.
} 
It is crucial situation for nation which sacrifices for bright future in the separate democratic state. It is felt publicly that it is only disillusions.

First Constituent Assembly tried curtailing powers, Governor General Ghulam Muhammad announced the dissolution of Assembly on October $24,1954^{10}$. He described the parliamentary bickering was going to an end ${ }^{11}$. Governor General having painstaking about political crises of country was faced and becoming deeper. It was observed and concluded that the breakdown of the constitutional apparatus and functioning of the governmental machinery. So, it was resolute to declare emergency throughout the country. The constituent assembly lost the confidence of the people and can no longer function. ${ }^{12}$

The Constituent Assembly approved the first Constitution of Pakistan which was promulgated on 23 March 1956. The Constitution of 1956 vested as the executive authority of President of federation of Pakistan. The Constitution awarded the discretionary powers of appointment the Election Commissioner with its members and Public Service Commission of Pakistan. The appointment of Prime Minister was also made by the President. He has to get vote of confidence in the period of two months. The Constitution of 1956 empowered President of Pakistan to remove the Prime Minister of Pakistan in case of losing confidence of majority of National Assembly members.

\footnotetext{
${ }^{10}$ Hamid Khan, Constitutional and Political History of Pakistan (Karachi: Oxford University Press, 2001), 136; Daily DAWN Karachi, 08 ${ }^{\text {th }}$ August 1978.

${ }^{11}$ G. W. Choudary, Constitutional Development in Pakistan (London: Longman Group Limited, 1969), 67.

${ }^{12}$ Choudary, 82.
} 
General Mohammad Ayyub khan abrogated the Constitution of 1956 and imposed martial law to take over the government on October 27, 1958. The existing political system was reversed by martial law. The development of democratic institutions was stopped.

There was serious issue has to face for institutional development in Pakistan. Without democratic institution it was hard task to formulate the state structure according to public wishes of state. General Muhammad Yahya decided to hold general election first time on adult franchise basis on March 1970. One Unit was ended on July 1, 1970. National Assembly consisted of 313 seats; 13 seats reserved for women. For peaceful transfer of power general election were held till October $22,1970 .{ }^{13}$

The role of political parties was much different till 1970. Zulfikar Ali Bhutto also raised the slogan, 'Islam and Democracy' while Sheikh Mujeeb-ur-Rehman led Awami League on six points agenda in East Pakistan and got outstanding majority in National Assembly in the general election of 1970. Agha Muhammad Yahya Khan was not willing for peaceful to hand over power to civil leadership. Awami Leagues started agitation and government failed to handle the situation. The military intervened in East Pakistan.

Yahya Khan handed over the governmental responsibilities to Zulfikar Ali Bhutto as a "Civil Martial Law Administrator" on December 20, 1971. After the implementation of Constitution 1973, took responsibilities of Prime Minister of Pakistan. The next general elections

${ }^{13}$ Zulfikar Ali Bhutto, The Great Tragedy (karachi: Pakistan People's Party Publications, 1971), 154. 
Appraisal of Islamic Democratization in Zia Ul-Haq Regime

were conducted on February 1977. Pakistan People party got 155 seats. Pakistan National Alliance refused to accept the results of general election. Pakistan National Alliance accused of rigging in the election. Therefore, the elections of provincial assemblies were boycotted. ${ }^{14}$

The movement of Nizam-e-Mustafa of Pakistan National Alliance was in full swung. During the movement of 1977 the slogan of Implication of Nizam-e-Mustafa, became popular and significant Islamic norms and principles to transform the political, social and administrative structure of state institutions. ${ }^{15}$ Pakistan National Alliance started countrywide protest on the issue of riggings in general election 1977 against government of Zulfikar Ali Bhutto. The public was interested to implementation of Islamic System of government in Pakistan. The ethnic violence confronted the state which reinforced the tendency to relay on Islam to organize national politics. ${ }^{16}$

Pakistan People's Party government started negotiation with Pakistan National Alliance to resolve the crisis. Several meetings were held between both the parties. The dialogue was going in positive direction. It was expectation that some concrete solution would be come out during dialogue. Zulfikar Ali Bhutto announced about the agreement during press conference which would be signed next day. But the situation was changed and martial law was imposed in the country.

\section{REGIME OF ZIA -UL-HAQ}

Pakistan military establishment intervened second time in politics on

${ }^{14}$ Daily DAWN Karachi, 08 ${ }^{\text {th }}$ August 1978.

15 Daily DAWN Karachi, $08^{\text {th }}$ August 1978.

${ }^{16}$ Waseem, "Functioning of Democracy in Pakistan," 177-218. 
Appraisal of Islamic Democratization in Zia Ul-Haq Regime

July 4, 1977, General Zia-ul-Haq took over the control of government of Pakistan. He suspended the Constitution of 1973 and imposed martial law in Pakistan. ${ }^{1}$ He was working as Army Chief as well as Martial law Administrator. General Zia-ul-Haq promised for the restoration of the democracy within 90 days in Pakistan. He became President of Pakistan in September 1978. Zulfikar Ali Bhutto was executed on July 4, 1979. These decisions of General Zia-ul-Haq changed the political scenario and general elections were postponed.

Islamist parties had religious sympathy with General Zia-ul-Haq. Therefore, these political parties were natural ally of General Zia-ul-Haq and adopted the identical approach during the martial period. Islam as a religion used for the stability of state. General Zia-ul-Haq used religion Islam as tool to prolong his era of government. The events in these three provinces deviated from the state's preoccupation with Islam. There is the pervasive role of Islam in the national life of people in the Islamic society of Pakistan. As it was observed that Jamat Islami was opposing the liberal political parties as well as military government but the coup d" etat of General Zia-ul-Haq was cause of change the nature of political relationship of Jamat Islami. General Zia-ul-Haq was also focusing to Islamize the society of Pakistan through governmental decision. Jamat Islami was also urging since inception of Pakistan. Maududi believed that this "struggle between Islam and non-Islam would culminate in an Islamic 
The Scholar Islamic Academic Research Journal

Vol. 5, No. 1 || January -June 2019 || P. 32-48

https://doi.org/10.29370/siarj/issue8ar10

revolution and the creation of an Islamic State which would in turn initiate large-scale reforms in society thereby leading to a utopian Islamic order."17

General Zia-ul-Haq was strengthening power. There was serious question to have the legitimacy to govern the people. The introduction of Islam democratic system of government was the best option. The campaign of lslamization in Pakistan was launched. The core objective is to ensure the public to get the control of government is to implement Islamic democratization in Pakistan. Islamic legal system based on Quran and Sunnah. The implementation of Islamic legal system could cause to evolve the Islamic society. ${ }^{18}$

Federal Sharia Court was established. The benches of Sharia Courts were established under Presidential Order which was issued on February 10, 1979. The High Courts were empowered to declare laws null and void under Presidential Order. There was some contravention of federal or provincial laws with Islamic laws and citizens have right to proceed through application/petition in Islamic Ideological Council. ${ }^{19}$

General Zia-ul-Haq restructured the Islamic Ideological Council. Its prime objective was conformity of existing laws with Islam. The banking system and tax system was conformity with Sharia. He focused on law, education, economy and culture. The prime function of the Council to

\footnotetext{
${ }^{17}$ Seyyed Vali Reza Nasr, The Vanguard of Islamic Revolution: The Jamaat-i-Islami of Pakistan (London: I. B. Tauris, 1994), 106.

${ }^{18}$ Afzal Iqbal, Islamisation of Pakistan (Lahore: Vanguard, 1986), 118.

${ }^{19}$ Hasan Askari Rizvi, The Military \& Politics in Pakistan 1947-86 (Lahore: Progressive, 1986), 234.
} 
The Scholar Islamic Academic Research Journal

Vol. 5, No. 1 || January -June 2019 || P. 32-48

https://doi.org/10.29370/siarj/issue8ar10

decide and gave recommendations about the laws with accordance of Quran and Sunnah. The Council took important steps for lslamization in Pakistan which were as, interval to say prayer during working hours in the offices, laws for Qișās, Diyet and interest free Islamic banking, implementation of Hudūd laws, Zakāt system, teaching of Islamiat and Pakistan Studied as compulsory subjects on B/A and B/Sc. ${ }^{20}$ These steps had substantial impact on the society on the other hand, it was expected that $H u d \bar{u} d$ laws may prove fruitful to decrease the crimes ratios. There were controversies about these laws and the sectarian differences cropped up which plagued the country political and social imbalance.

The Council reviewed laws 235 for further recommendations. There were 66 laws forwarded to federal sharia court. General Zia-ul-Haq established Majlis-e-Shura to maintain liaison between the public and the government. The members of Majlis-e-Shura were nominated. The major objective of the establishment of Majlis-e-Shura to convey the message that the Islamic democratic had been started. The final authority was belonged to President so that Majlis-e-Shura had no substantial bearing. ${ }^{21}$

The political parties sponsored political alliance on specific points as, "Alliance sponsored a four-point programmed, an end of Martial Law, Restoration of the 1973 Constitution, Parliamentary elections and Transfer of power to public representatives" 22 "Movement of Restoration of Democracy' was launched in 1983. MRD movement crushed forcefully.

General Zia-ul-Haq held the Presidential referendum to legitimate

\footnotetext{
${ }^{20}$ Afzal Iqbal, Islamisation of Pakistan, 118.

${ }^{21}$ Shahid Javed Burki and Craig Baxter, Pakistan Under The Military: Eleven Years Of Zia Ul-Haq (America: westview press, 1991), 36-37.

${ }^{22}$ Mohammad Waseem, The 1993 Elections in Pakistan (Vanguard, 1994), 193.
} 
The Scholar Islamic Academic Research Journal

Vol. 5, No. 1 || January -June 2019 || P. 32-48

https://doi.org/10.29370/siarj/issue8ar10

the martial law on December 19, 1984. The question was asked you wanted Islam in Pakistan, and then General Zia-ul-Haq became President of Pakistan for next term. It was confirmation of 1slamization policy of General Zia-ul-Haq which was interpretation for General Zia-ul-Haq Presidency. Election Commission of Pakistan announced that he got $98 \%$ vote in this referendum. ${ }^{23}$ The masses of Pakistan did not proper response on the appeal of leadership of MRD. The majority of people respond to Presidential Referendum.

General Zia-ul-Haq instituted local government system. Three tiers of local government system were introduced as, union council, tehsil council and zilla council. There were town committee, municipal committee and metropolitan corporations. The councilors of three tiers were elected for four years and might be re-elected for next term. The public participated in democratic process which was started from grass root level. The councilors should have to concentrate to improve the local governing system and have to focus on agriculture production, health, education, water supply and roads. The voting process was based on nonparty.

The general elections were held on February 25 and 28 for National and Provincial Assemblies respectively. "Over twelve hundred candidates contested for the 207 National Assembly seats for the Muslims." The turnout for the general election was $52 \%$ which was surprising for government as well as opposition. ${ }^{24}$ General Muhammad Zia-ul-Haq and his allies were satisfied from the cast rate of general elections. The major

\footnotetext{
${ }^{23}$ Mohammad Waseem, Pakistan under Martial Law, 1977-1985 (Lahore: Vanguard, 1987), 8.

${ }^{24}$ Afzal Iqbal, Islamisation of Pakistan, 130-32.
} 
The Scholar Islamic Academic Research Journal

Vol. 5, No. 1 || January -June 2019 || P. 32-48

https://doi.org/10.29370/siarj/issue8ar10

prominent political parties were appeal for the boycott of the electoral process. Pakistan People's Party and some other major political parties boycotted voting process on polling day and the people follow the appeal of the boycott. On the other hand, the government had official stance that the people participated in the electoral process and masses did not take effect from the appeal of boycott.

There were serious challenges due to non-party election of 1985 in Pakistan. The election campaign was based on clan, caste and brothery issue. As it was highlighted by Omar Noman as, "tribe, clan, sect and ethnicity are factor that appear to be serving or framers of reference for the voters in today's electoral contest". ${ }^{25}$ Tahir Amin has critics of general election 1985 in this way, "the most significant consequence of the party less elections have been that the political campaign inevitable revolved around tribal, ethnic and sectarian issues in the absence of any program. Regime claimed the elections had one propose to take forward the process of 1slamization with the participation of the people. But it was not seen during the elections, majority of the candidate were talk about the local issues and convinced to the people on his personal and ethnic and tribal relations." 26 The views of Rai Shakil Akhtar related to electoral process were described as, "Elections primarily concerned with local issue and seldom took up bigger national issue. Islam, Democracy, Martial Law, economy foreign affairs, was not part of electioneering. These elections reduced national politics to municipal level.,27

\footnotetext{
${ }^{25}$ Omar Noman, The Political Economy of Pakistan 1947-58 (London: KPI, 1988), 127.

${ }^{26}$ Tahir Amin, Ethno National Movements of Pakistan Domestic and International Factors (Islamabad: Institute of Policy Studies, 1993), 18.

${ }^{27}$ Akhtar Akhtar, Media, Religion and Politics in Pakistan (Karachi: Oxford University Press, 2000), 179.
} 
The Scholar Islamic Academic Research Journal

Vol. 5, No. 1 || January -June 2019 || P. 32-48

https://doi.org/10.29370/siarj/issue8ar10

The political scientists and political scholars have observation the electoral process conducted on the nonparty basis led to deep impact on the democratic process. The democratic process in Pakistan was observed as negative impact due to nonparty political activities which led to regional and ethnic politics. MQM and PPI like parties were the outcomes of the nonparty political activities in General Zi-ul-Haq regime.

Benazir Bhutto was prominent political leaders believed on strong federation having opinion as, "The non-party elections held by the regime had furthered the country's fragmentation. By banning political parties, the regime forced candidates to campaign not on a platform of political ideals, which transcended ethnic and regional boundaries, but on the basis of individual identification. Vote for me, I'm a Shiite like you, candidate in these elections told their constituents. Vote for me, I'm a Punjabi". ${ }^{28}$

Dr Tahir Amin analytical views were expressed as, "opportunist local holders principally the land-owning rural class emerged victorious in the elections and the regime was more than happy to make them a junior partner in the power game both at the center and in the provinces". ${ }^{29}$

The use of financial resources to contest the general election was considered undemocratic tradition. The non-party elections were also considered to bring business class political leadership. These members involved in financial corruptions and personal interests.

Pakistan Peoples Party boycotted the non-party elections of 1985. The majority of Cabinet Ministers and members of Majilis Shoora were

\footnotetext{
${ }^{28}$ Benazir Bhutto, Daughter of East, An Autobiography (London: UK Mandarin Paperbacks, 1994), 313.

${ }^{29}$ Tahir Amin, Ethno National Movements of Pakistan Domestic and International Factors, 18.
} 
The Scholar Islamic Academic Research Journal

Vol. 5, No. 1 || January -June 2019 || P. 31-47

https://doi.org/10.29370/siarj/issue8ar10

got defeat in general election. It proved that the electoral process was transparent and the elections were free and fair. The participation of masses in the general election proved helpful to leave the Martial Law in Pakistan. The public has aspiration to promote the democratic process in the Pakistan. The elections were the performing the key role to establish democratic system in Pakistan. The voters were convinced to cast vote to strengthen the democratic process in Pakistan.

General Zia-ul-Haq was not in favor of political parties' role in the government. Although the political parties were the major tool of democratic process but the role of parties was lessened to conduct nonparty basis elections. The non-party elections were not favored in the democratization. The non-party basis election weakened the political parties grip on the governing system in Pakistan. The political scientist studied the decision for conversion of parliamentary system of government to presidential system of government. It was evident when amended Constitution of 1973 was reinstated in 1985. National Assembly approved $8^{\text {th }}$ amendment in November in $1985 .^{30}$ The constitutional amendments made the President powerful instead of Prime Minister in parliamentary form of government. President had authority to suspend the government and dissolve the National Assembly without consult of Prime Minister of Pakistan. the constitutional changes not only change the power pillar but also the system of government which was parliamentary to presidential form of government in authority of President of Pakistan.

\footnotetext{
${ }^{30}$ The Gazette of Pakistan, 1985.
} 
The Scholar Islamic Academic Research Journal

Vol. 5, No. 1 || January -June 2019 || P. 31-47

https://doi.org/10.29370/siarj/issue8ar10

Political Structures of Government in Pakistan under $8^{\text {th }}$ Amendment

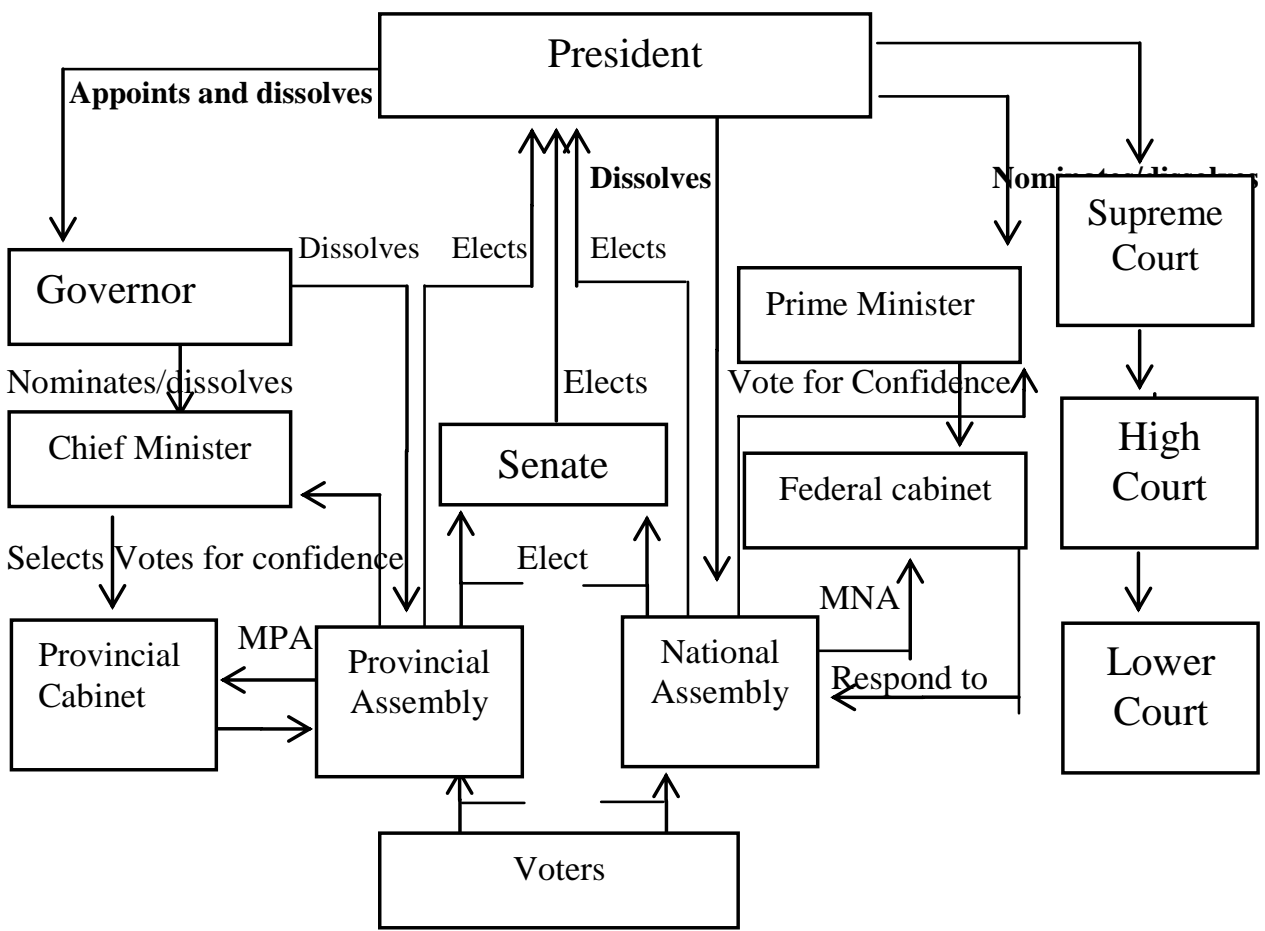

There was clash between Head of State and Head of Government on policy issues. General Zia-ul-Haq dismissed the government of Muhammad Khan Junejo and dissolved the National Assembly on May 29, 1988. President of Pakistan was awarded the power to dissolve the Assembly under Article 58(2b) of Constitution 1973. It was blamed that Assembly was failed to achieve the basic objectives to constitute the Assembly. The government was also failed to face the challenge of economic chaos and crisis as well as law and order situation of the country. Prime Minister of Pakistan neglected the lslamization process in 
The Scholar Islamic Academic Research Journal

Vol. 5, No. 1 || January -June 2019 || P. 31-47

https://doi.org/10.29370/siarj/issue8ar10

Pakistan. ${ }^{31}$ On July 20, 1988, he announced to hold general election on November 16, 1988. He was died in an airplane on August 17, 1988.

\section{CONCLUSION}

The ethnic and regional as well as religious factors were emerged due to non-party basis election during General Zia-ul-Haq. Members parliament elected without agenda of serious concerns of Pakistan. Resultantly people of Pakistan were divided in to caste, clan and sect which led to divided society state. The integrity of state was gone into waved. Consequently, the democratic process was not got mature. There was hot debate either Islamic democratic system be implemented or not in Pakistan. The business class of political leadership was emerged which led the society to corrupt political leadership.

\section{@()@(@)}

This work is licensed under a Creative Commons Attribution-NonCommercial-ShareAlike 4.0 International (CC BY-NC-SA 4.0)

\footnotetext{
${ }^{31}$ Lawrence Ziring, Pakistan in the Twentieth Century: A Political Study (Karachi: Oxford University Press, 1997), 500-501.
} 